\title{
PENGGUNAAN CARBOXYMETHYL CELLULOSE (CMC) DAN KARAGENAN TERHADAP KARAKTERISTIK VELVA NENAS (Ananas comosus) - SAWI (Brassica juncea L.)
}

\author{
(The use of Carboxymethyl Cellulose (CMC) and carrageenan on the characteristics of \\ pineapple (Ananas comosus) - mustard greens (Brassica juncea L.) velva)
}

\author{
Azlin Meirina ${ }^{1}$, Zaidiyah ${ }^{1}$, Syarifah Rohaya ${ }^{1 *}$ \\ ${ }^{1}$ Program Studi Teknologi Hasil Pertanian, Fakultas Pertanian, Universitas Syiah Kuala \\ *Corresponding author: syarifahrohaya @ unsyiah.ac.id
}

\begin{abstract}
Abstrak. Penelitian ini bertujuan untuk mengetahui karakteristik fisikokimia dan organoleptik velva berbasis nenas-sawi. Penelitian ini menggunakan Rancangan Acak Kelompok (RAK) faktorial dengan 2 (dua) faktor, yaitu perbandingan rasio nenas dan sawi dan jenis penstabil. Faktor 1 (satu) yaitu perbandingan konsentrasi nenas dan sawi (V) yang terdiri atas 3 (tiga) taraf diantaranya V1=60:40, V2=40:60 dan V3=50:50. Sedangkan faktor 2 (dua) yaitu jenis penstabil $(\mathrm{P})$ yang terdiri dari 2 (dua) taraf diantaranya $\mathrm{P} 1=\mathrm{CMC}$ dan $\mathrm{P} 2=$ karagenan. Sehingga didapatkan kombinasi perlakuan yaitu $3 \times 2=6$ dengan ulangan sebanyak 3 (tiga) kali sebagai kelompok dan didapatkan 18 satuan percobaan. Hasil dari penelitian ini yaitu velva nenas sawi dengan formula terbaik adalah yaitu dengan rasio nenas dan sawi 40:60 dengan jenis penstabil CMC nilai overrun 34.75\%, viskositas 2988.27 cP, daya leleh 30.93 menit, serat kasar $14.05, \mathrm{pH} 4.71$, kadar air $80.69 \%$, kadar abu $0.192 \%$, total padatan terlarut 12.97 , vitamin c $27.37 \%$. Berdasarkan pengujian hedonik oleh panelis semi terlatih, rasio velva yang paling diminati secara keseluruhan yaitu rasio nenas dan sawi 50:50 menggunakan penstabil karagenan. Rasio nenas dan sawi (V) dan jenis penstabil (P) serat interaksi keduanya (VP) berpengaruh sangat nyata terhadap nilai viskositas, daya leleh, $\mathrm{pH}$, total padatan terlarut, dan rasa velva nenas sawi.
\end{abstract}

Kata kunci: velva, CMC, karagenan.

\begin{abstract}
The aim of this study was to determine the physicochemical and organoleptic characteristics of the pineapple-mustard greens velva. This study used a factorial Randomized Block Design (RAK) with 2 (two) factors, namely the ratio of pineapple and mustard greens and the type of stabilizer. Factor 1 (one) is the ratio of the concentration of pineapple and mustard greens (V) which consists of 3 (three) levels including V1=60:40, $\mathrm{V} 2=40: 60$ and $\mathrm{V} 3=50: 50$. While factor 2 (two) is the type of stabilizer (P) which consists of 2 (two) levels including $\mathrm{P} 1=\mathrm{CMC}$ and $\mathrm{P} 2=$ carrageenan. So that the treatment combination was obtained, namely $3 \times 2=6$ with 3 (three) replications as a group and 18 experimental units were obtained. The result of this research is that the pineapple- mustard greens velva with the best formula is the ratio of pineapple-mustard greens 40:60 with the type of stabilizer CMC 34.75\% overrun value, viscosity $2988.27 \mathrm{cP}$, melting point 30.93 minutes, crude fiber $14.05 \%$, pH 4.71 , water content $80.69 \%$, ash content $0.192 \%$, total dissolved solids 12.97 , vitamin C $27.37 \mathrm{mg} / 100$ gram. Based on hedonic testing by semi-trained panelists, the most desirable velva ratio overall is the 50:50 ratio of pineapple - mustard greens using carrageenan stabilizer. The ratio of pineapple and mustard (V) and the type of stabilizer $(\mathrm{P})$ of the interaction between the two fibers (VP) had a very significant effect on the value of viscosity, melting point, $\mathrm{pH}$, total dissolved solids, and taste of pineapple- mustard greens velva.
\end{abstract}

Keywords: velva, CMC, carageenan

\section{PENDAHULUAN}

Nenas (Ananas comoscus) adalah salah satu jenis buah tropis yang keberadaannya tersebar hampir di seluruh wilayah Indonesia, dengan produksi mencapai 2.196. 456 ton pada tahun dari area panen seluas 17116 ha. Buah ini terkenal dengan permukaan kulit buah bersisiksisik, memiliki gabungan rasa asam dan manis dan kandungan vitamin $\mathrm{C}$ serta seratnya. Olahan nenas yang sering dijumpai diantaranya yaitu minuman jus nenas dan sari buah nenas. Sawi (Brassica juncea L.) merupakan jenis sayuran yang dikonsumsi dalam bentuk segar oleh 
masyarakat, sebagai pelengkap di olahan sayuran atau dijadikan lauk (Irawan, 2016). Sawi juga dapat diolah menjadi jus, es krim dan velva.

Masyarakat sudah banyak membuat minuman kesehatan dengan cara mencampur jus buah dengan sayuran diantaranya minuman jus nenas sawi yaitu minuman jus nenas yang dikombinasikan dengan sayuran sawi. Selain dibuat jus, kombinasi nenas dan sawi juga dapat dibuat sebagai produk beku seperti velva sebagai salah satu alternatif pengolahan makanan (Kusbiantoro, $d k k, 2005$ ). Pengolahan pada suhu rendah dapat menekan laju kerusakan, laju pertumbuhan mikroba serta laju respirasi, sehingga dapat memperpanjang umur simpan produk (Harnanik 2013).

Velva termasuk salah satu olahan pangan beku mirip es krim dengan kandungan lemak yang rendah (Ulya, 2019). Velva menjadi salah satu makanan pencuci mulut alternatif yang tidak menggunakan susu dan turunannya sehingga sesuai untuk orang yang mengalami lactose intolerance. Velva memiliki komponen nutrisi yang berbeda-beda tergantung dengan bahan penyusunnya. Velva dapat dibuat dari berbagai jenis buah dan sayur-sayuran dan bahkan kombinasi keduanya, seperti yang akan dilakukan pada penelitian ini yaitu kombinasi nenas dan sawi.

Salah satu faktor yang mempengaruhi mutu velva yaitu penstabil. Pada pengolahan velva, perlu diperhatikan jenis dan banyaknya konsentrasi bahan penstabil yang digunakan, serta total padatan yang ditambahkan. Dengan rasio yang tepat, velva buah yang dihasilkan akan memiliki tekstur yang halus dan lembut di mulut. Pada produk olahan velva, penstabil yang umum digunakan adalah carboxymethyl cellulose (CMC), gelatin gum arab dan karagenan (Tantono, $d k k$, 2017). Dalam penelitian ini, penstabil yang digunakan yaitu CMC dan karagenan.

\section{METODE PENELITIAN}

Penelitian ini dilakukan pada bulan Oktober sampai November 2020 di Laboratorium Rekayasa Pangan dan Industri. Analisis pengujian produk dilakukan di Laboratorium Analisis Pangan dan Hasil Pertanian, Laboratorium Uji Sensori, Program Studi Teknologi Hasil Pertanian, Fakultas Pertanian, Universitas Syiah Kuala.

\section{MATERI DAN METODE}

\section{Bahan dan Alat}

Adapun bahan yang digunakan dalam penelitian ini yaitu bahan utama yang terdiri dari nenas jenis cayene yang sudah matang secara fisiologis, berwarna hijau kekuningan atau oranye, bertekstur sedikit lunak tanpa ada memar atau busuk pada permukaan kulit buah dan sawi jenis caisim, berwarna hijau segar dan tidak layu serta daunnya tidak berlubang. Selanjutnya bahan pendukung yang terdiri dari bahan penstabil carboxymethyl cellulose (CMC) merek Koepoe, karagenan jenis iota (Euchema Spinosium) dari toko online "taminaa" yang dibeli menggunakan aplikasi Shopee, gula pasir, air, asam sitrat merek Citrun Zuur dan bahanbahan kimia yang digunakan untuk analisis yaitu heksan, $\mathrm{NaOH}, \mathrm{H}_{2} \mathrm{SO}_{4}$, amilum, larutan iodin dan aquades.

Alat yang digunakan pada penelitian ini adalah timbangan digital, pisau, baskom, ice cream maker, lemari pendingin, sendok, blender. Alat-alat yang digunakan untuk analisis sifat fisik kimia diantaranya adalah refraktometer, $\mathrm{pH}$ meter, gelas ukur, labu ukur, cawan petri, gelas piala, kertas saring, blanko, desikator, inkubator, pipet tetes, oven, tanur pengabuan, dan alat pelengkap lainnya serta alat untuk pengujian organoleptik berupa kuisioner. 


\section{Metode Penelitian}

Penelitian ini menggunakan Rancangan Acak Kelompok (RAK) faktorial dengan 2 (dua) faktor, yaitu perbandingan rasio nenas dan sawi dan jenis penstabil. Faktor 1 (satu) yaitu perbandingan rasio nenas dan sawi $(\mathrm{V})$ yang terdiri atas 3 (tiga) taraf diantaranya $\mathrm{V} 1=60: 40$, $\mathrm{V} 2=40: 60$ dan $\mathrm{V} 3=50: 50$. Sedangkan faktor 2 (dua) yaitu jenis penstabil $(\mathrm{P})$ yang terdiri dari 2 (dua) taraf diantaranya $\mathrm{P} 1=\mathrm{CMC}$ dan $\mathrm{P} 2=$ karagenan. Sehingga didapatkan kombinasi perlakuan yaitu 3x2=6 dengan ulangan sebanyak 3 (tiga) kali sebagai kelompok dan didapatkan 18 satuan percobaan. Data yang didapatkan dari hasil penelitian selanjutnya dianalisis menggunakan Analysis of varience (ANOVA). Jika hasil analisis menunjukkan pengaruh yang nyata dan sangat nyata, selanjutnya akan dilakuan uji lanjut untuk mengetahui pengaruh dari masingmasing taraf.menggunakan uji Duncan Multiple Range Test (DMRT).

\section{Prosedur Penelitian}

Buah nenas masak disortasi kemudian dikupas dan dicuci bersih dengan air mengalir lalu dipotong menjadi potongan kecil sebanyak sesuai perlakuan. Sawi disortasi terletbih dahulu, dipisahkan daun dari batangnya sebanyak sesuai perlakuan kemudian daunnya dicuci bersih dengan air mengalir. Daun sawi diblansir selama 5 menit dengan air sebanyak $90 \mathrm{ml}$. Air masak/air minum disiapkan sebanyak $30 \mathrm{ml}$ dan ditimbang gula pasir sebanyak $20 \mathrm{~g}$ serta asam sitrat sebanyak $0,1 \%$ dari berat total. Potongan nenas, sawi yang telah diblansir, gula, air, asam sitrat dan penstabil 1\% (CMC dan karagenan) dari total bahan (Sulastri, 2008) dihomogenkan menggunakan blender selama 5 menit hingga halus sesuai perlakuan. Adonan dimasukkan ke dalam icecream maker selama 30-45 menit. Velva kemudian dimasukkan ke dalam wadah dan dibekukan dalam freezer.

\section{Analisis Velva nenas-sawi}

Analisis yang dilakukan diantaranya adalah analisis fisik yaitu daya leleh, overrun, dan viskositas, dan analisis kimia yang mencakup padatan terlarut, nilai $\mathrm{pH}$, kadar serat kasar, kadar air, kadar abu dan vitamin C, serta uji organoleptik (uji hedonik) yang terdiri dari warna, aroma, rasa, tekstur dan overall acceptablity.

\section{HASIL DAN PEMBAHASAN}

\section{Overrun}

Overrun merupakan banyaknya kumpulan udara yang masuk dalam adonan velva saat proses pengadukan yang membuat volume velva meningkat. Menurut Arbuckle (1986) banyaknya udara yang terperangkap pada proses pembuatan yang menambah volume produk. Semakin banyak udara yang terperangkap dalam pengadukan maka volume produk akan meningkat. Berdasarkan hasil penelitian, overrun velva nenas sawi berkisar antara $30 \%$ hingga $39.75 \%$ dengan rata rata $34.51 \%$.

Penggunaan rasio nenas dan sawi 40:60 mengandung lebih banyak serat dibandingkan dengan rasio lain. Menurut TKPI Kemenkes, 2019, berdasarkan bahan baku, kadar serat sawi yaitu $2.6 \%$ sedangkan nenas $0.6 \%$, sehingga didapatkan perbedaan nilai overrun pada tiap rasio nenas dan sawi. 


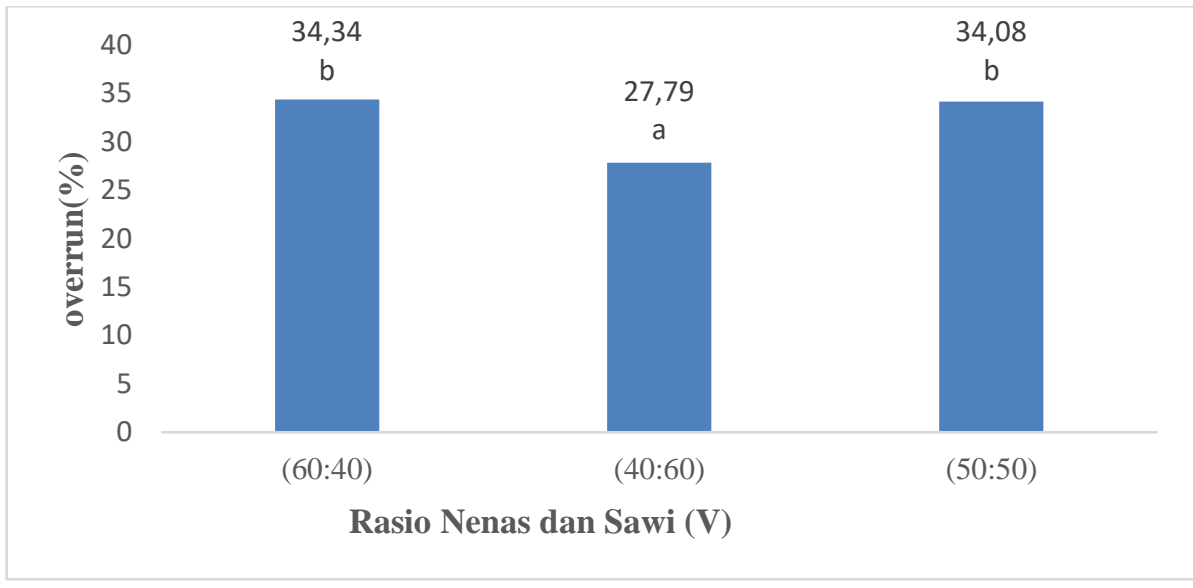

Gambar 1. Pengaruh rasio nenas dan sawi (V) terhadap overrun (\%) (Nilai yang diikuti huruf yang berbeda menunjukkan perbedaan yang nyata pada uji DMRT 0,05 taraf $2=3,15$, taraf $3=3,29$, taraf $4=3,38$, taraf $5=3,43$ dan $\operatorname{taraf} 6=3,46)$.

\section{Viskositas}

Viskositas yaitu hambatan aliran suatu larutan atau molekul akibat pergerakan. Viskositas dalam suatu produk dapat ditingkatkan dengan menambahkan penstabil dalam produk tersebut (Priastami, 2011). Berdasarkan hasil penelitian, viskositas velva nenas sawi berkisar antara $1525.4 \mathrm{cP}$ hingga $4067.3 \mathrm{cP}$ dengan rata rata $2792.4 \mathrm{cP}$.

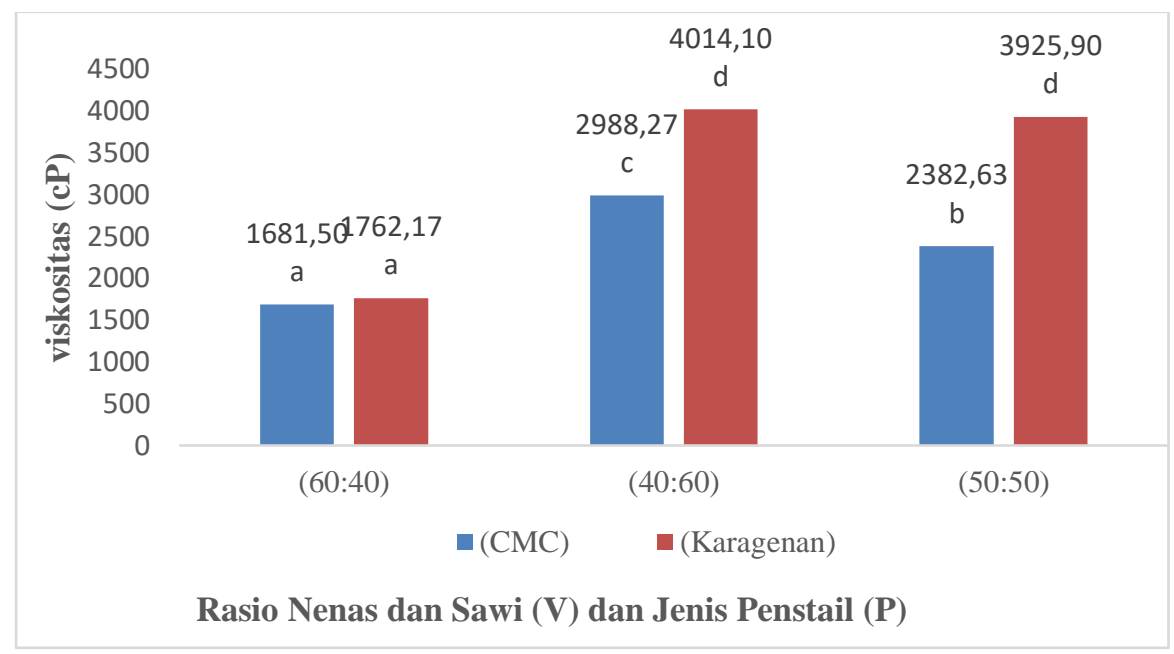

Gambar 2. Pengaruh rasio nenas dan sawi (V) dan jenis penstabil (P) terhadap viskositas (cP) (Nilai yang diikuti huruf yang berbeda menunjukkan perbedaan yang nyata pada uji DMRT 0,05 taraf $2=3,15$, taraf $3=3,29$, $\operatorname{taraf} 4==3,38$, taraf $5=3,43$ dan taraf $6=3,46$ ).

Jihan (2020) menjelaskan penggunaan karagenan dengan rasio jumlah sawi yang lebih banyak mampu mengoptimumkan fungsi karagenan dan mendorong terbentuknya gel. Menurut Thakur dan Thakur, (2016), tipe karagenan iota mampu optimum dan membentuk gel pada adonan dengan kalsium lebih banyak. Berdasarkan bahan baku, kalsium pada sawi dapat mencapai $220 \mathrm{mg}$ per 100 gram bahan sedangkan pada nenas hanya $22 \mathrm{mg}$ per 100 gram bahan. Velva dengan rasio sawi lebih banyak mengandung kalsium yang lebih banyak dan $\mathrm{pH}$ nya 
tidak terlalu rendah, sehingga karagenan diduga mampu bekerja optimum dan menghasilkan nilai viskositas lebih tinggi dari rasio lain.

\section{Daya Leleh}

Daya leleh adalah waktu yang dibutuhkan oleh makanan beku hingga dapat meleleh secara sempurna pada suhu ruang. Daya leleh memiliki hubungan yang erat dengan kekentalan adonan serta overrun. Semakin besar nilai overrun maka produk akan semakin cepat juga meleleh, namun jika nilai viskositas produk tinggi maka waktu meleleh yang dibutuhkan akan semakin lama (Firdaus, 2018). Berdasarkan hasil penelitian, daya leleh velva nenas sawi berkisar antara 17.96 menit hingga 38.33 menit dengan rata rata 27.94 menit.

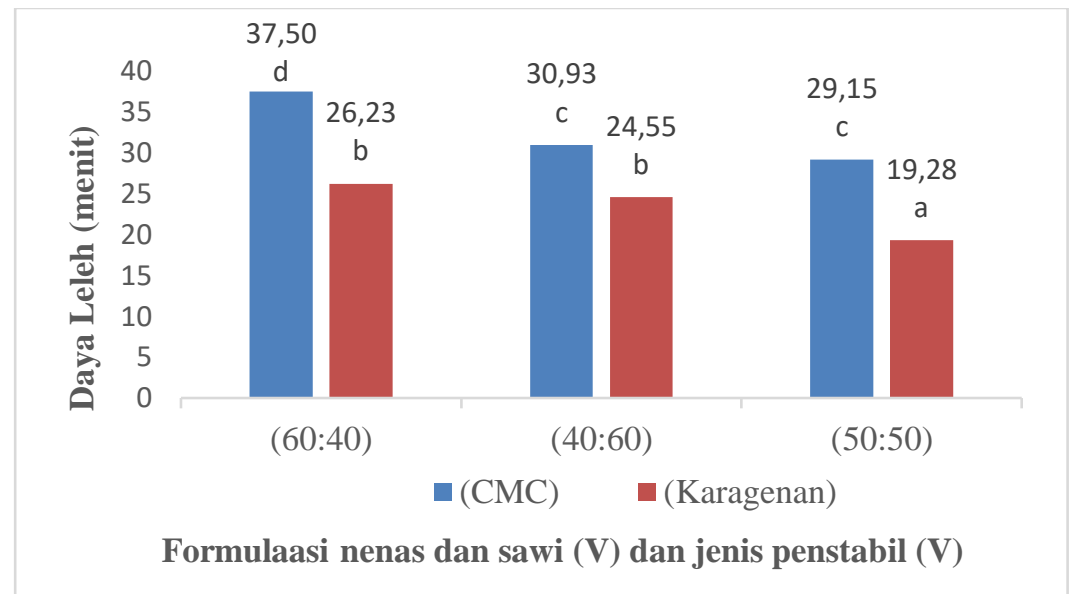

Gambar 3. Pengaruh rasio nenas dan sawi (V) dan jenis penstabil (P) terhadap daya leleh (Nilai yang diikuti huruf yang berbeda menunjukkan perbedaan yang nyata pada uji DMRT 0,05 taraf $2=3,15$, taraf $3=3,29$, taraf $4==3,38$, taraf $5=3,43$ dan taraf $6=3,46)$

Pada saat pencampuran semua bahan menggunakan blender, adonan dengan penstabil CMC terlihat lebih kental. Salah satu fungsi CMC yaitu sebagai pengental (Masyithah, 2020). Widiantoko (2014) menyebutkan bahwa CMC dan gum arab mampu mengikat air bebas lebih banyak dari karagenan, sehingga penggunaan $\mathrm{CMC}$ dapat menunda pelelehan lebih lama daripada karagenan. Velva dengan nilai overrun rendah akan lebih lama meleleh. Ini dikarenakan terdapat lebih banyak padatan dalam adonan, sehingga membutuhkan waktu yang lebih lama untuk mencair. Jika dibandingkan dengan velva dengan overrun tinggi, gelembunggelembung udara pada velva lebih banyak, sehingga waktu velva untuk mencair lebih cepat (Sholihah, $d k k, 2017$ ).

\section{Serat Kasar}

Serat kasar adalah sisa atau residu bahan makanan setelah perlakuan asam dan basa yang didihkan, yang biasanya terdiri dari pentosan, selulosa, lignin serta beberapa zat lain (Kesuma, 2011). Berdasarkan hasil penelitian, serat kasar velva nenas sawi berkisar antara $9.9 \%$ hingga $15.91 \%$ dengan rata rata $12.80 \%$. Berdasarkan bahan baku, sawi hijau mengandung serat kasar sebesar 4.63\% (Nanggiang, 2016), dan nenas mengandung serat kasar sebesar $2.40 \%$ (Khoirunnisa dan Majid, 2014). 
pH

Nilai pH yaitu suatu derajat keasaman atau kebasaan suatu larutan. Nilai $\mathrm{pH}$ akan semakin tinggi jika konsentrasi ion hidrogen rendah (Maria dan Zubaidah, 2014). Berdasarkan hasil penelitian, $\mathrm{pH}$ velva nenas sawi berkisar antara 4.64 hingga 4.77 dengan rata rata 4.71 .

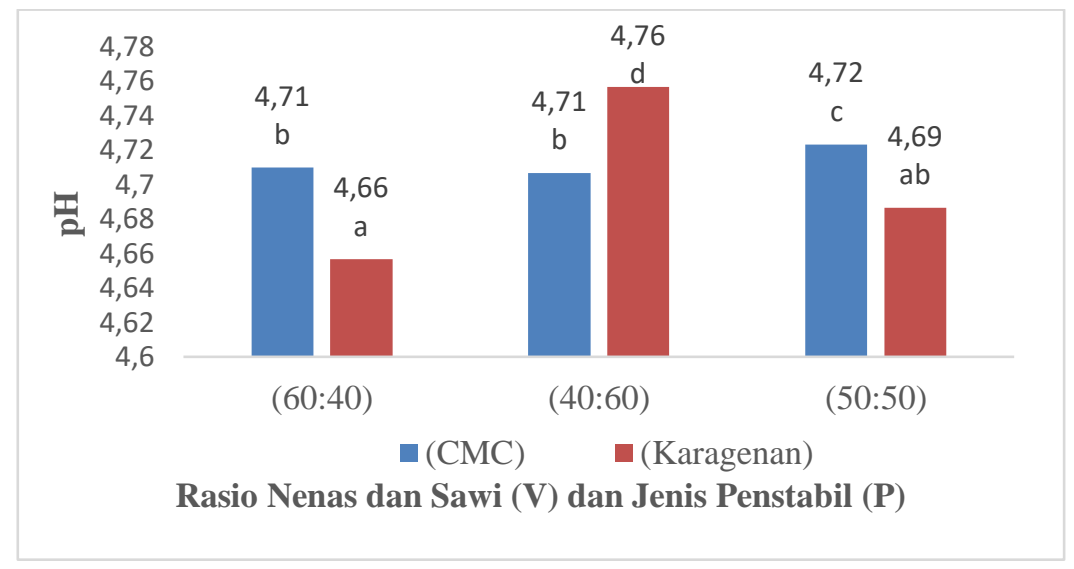

Gambar 4. Pengaruh rasio nenas dan sawi (V) dan jenis penstabil (P) terhadap $\mathrm{pH}$ (Nilai yang diikuti huruf yang berbeda menunjukkan perbedaan yang nyata pada uji DMRT 0,05 taraf $2=3,15$, taraf $3=3,29$, taraf $4==3,38$, taraf $5=3,43$ dan taraf $6=3,46)$.

Rasio dengan penambahan nenas yang lebih banyak menjadikan nilai $\mathrm{pH}$ lebih rendah dibandingkan dengan rasio lainnya. Nenas memiliki derajat keasaman sebesar 3.46 (Kumalasari, $d k k$, 2017). Menurut Pokluda (2007) sawi hijau memiliki derajat keasaman sebesar 5.8. nilai $\mathrm{pH}$ bubur nanas yang rendah dipengaruhi oleh kandungan asam-asam organik yang ada didalamnya (Tampubolon, 2017).

\section{Kadar Air}

Berdasarkan hasil penelitian, kadar air velva nenas sawi berkisar antara $78.32 \%$ hingga $85.5 \%$ dengan rata rata $81.56 \%$. Nurjannah (2003) menyebutkan nilai kadar air bertolak belakangan dengan nilai kekentalan. Semakin meningkatnya nilai kekentalan maka akan semakin menurun nilai kadar air. Ini dapar terjadi karena sejumlah air dapat terikat dan terperangkap pada matriks bahan sehingga ketika dilakukan pengukuran kadar air bernilai rendah.

\section{Kadar Abu}

Kadar abu merupakan residu bahan anorganik setelah bahan makanan dan bahan organik melewati proses penghancuran atau destruksi (Nurjannah, 2003). Nilai kadar abu dipengaruhi oleh unsur-unsur mineral yang terdapat dalam bahan pangan (Winarno, 2008). Berdasarkan hasil penelitian, kadar abu velva nenas sawi berkisar antara $0.184 \%$ hingga $0.222 \%$ dengan rata rata $0.194 \%$.

\section{Total Padatan Terlarut}

Berdasarkan hasil penelitian, total padatan terlarut velva nenas sawi berkisar antara 13 ${ }^{\circ}$ Brix hingga $15.8{ }^{\circ}$ Brix dengan rata rata $14.02^{\circ}$ Brix. 


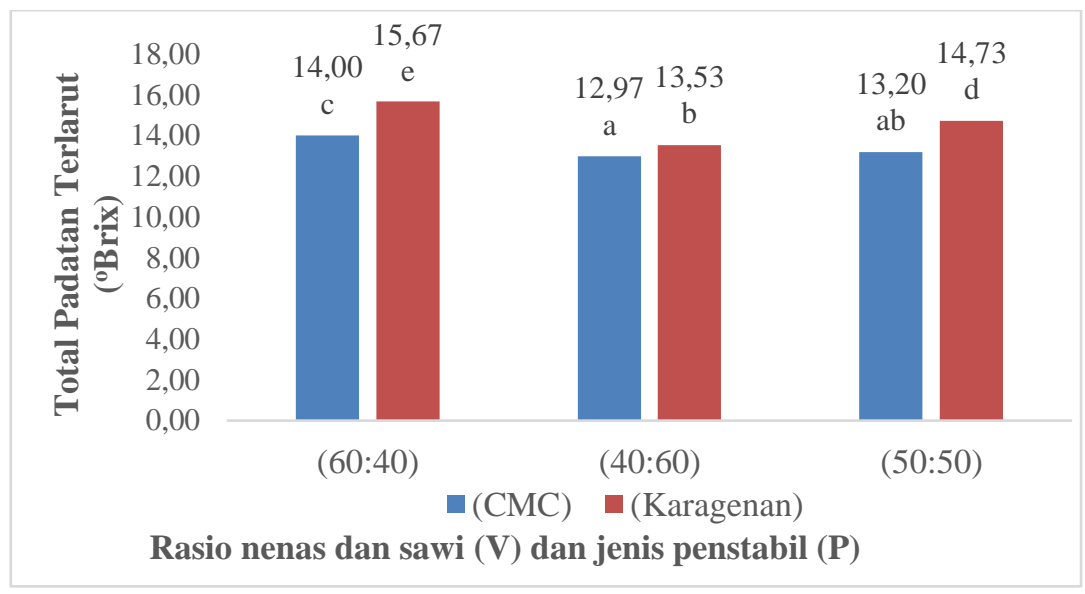

Gambar 5. Pengaruh rasio nenas dan sawi (V) dan jenis penstabil (P) terhadap total padatan terlarut $\left({ }^{\circ}\right.$ Brix) (Nilai yang diikuti huruf yang berbeda menunjukkan perbedaan yang nyata pada uji DMRT 0,05 taraf $2=3,15$, taraf $3=3,29$, taraf $4==3,38$, taraf $5=3,43$ dan taraf $6=3,46$ ).

Menurut Satriono, $d k k$ (2018) nenas memiliki total padatan terlarut sebesar $8.72{ }^{\circ}$ Brix sedangkan sawi memiliki total padatan sebesar $2.6^{\circ}$ Brix (Robert, 2007), sehingga rasio nenas dan sawi 60:40 memiliki nilai total padatan terlarut paling tinggi dibandingkan rasio lainnya. Nilai padatan terlarut produk akan lebih tinggi jika komponen-komponen penyusut, air, gula serta asam-asam organik terikat dengan baik. Sehingga baik CMC maupun karagenan mampu meningkatkan nilai total padatan terlarut jika semua komponen dapat terikat dengan baik dan stabil (Sulastri, 2008).

\section{Vitamin C / asam askorbat}

Berdasarkan hasil penelitian, vitamin C velva nenas sawi berkisar antara $21.12 \mathrm{mg} / 100 \mathrm{~g}$ hingga $31.68 \mathrm{mg} / 100 \mathrm{~g}$ dengan rata rata $25.49 \mathrm{mg} / 100 \mathrm{~g}$. Beberapa tahapan pengolahan velva seperti pemotongan, menghomogenan serta pembekuan selain itu terpaparnya cahaya dan oksigen diduga dapat mengurangi kadar vitamin $\mathrm{C}$ dalam velva. Ini sesuai dengan pernyataan Idah, $d k k$ (2015) dan Kesuma (2011) dimana pengurangan / degradasi kadar vitamin C dapat dipengaruhi oleh pengolahan produk, sinar, suhu tinggi serta oksigen.

\section{Sifat Organoleptik \\ Warna}

Berdasarkan hasil penelitian, nilai organoleptik warna velva nenas sawi berkisar antara 1.65 hingga 3.33 dengan rata rata 2.69. Menurut Desrosier, $d k k$ (1988), kenampakan warna bahan pada suatu makanan ditentukan oleh bahan pangan itu sendiri untuk menyerap, menyebar, meneruskan serta memantulkan sinar tampak. Warna produk dapat dipengaruhi proses pengolahan yang memperngaruuhi sifat fisik dan kimia produk.

\section{Aroma}

Aroma merupakan hasil rangsangan yang tercium oleh tubuh, yang dapat menjadi indikator khas suatu produk. Berdasarkan hasil penelitian, nilai organoleptik aroma velva nenas sawi berkisar antara 2.73 hingga 3.65 dengan rata rata 3.24 . 


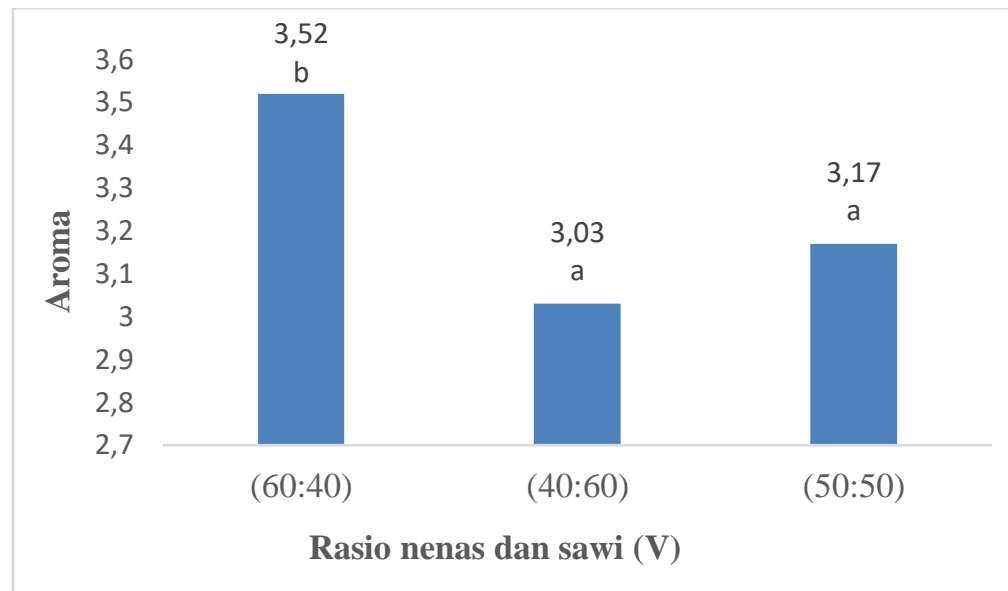

Gambar 6. Pengaruh rasio nenas dan sawi (V) terhadap aroma (Nilai yang diikuti huruf yang berbeda menunjukkan perbedaan yang nyata pada uji DMRT 0,05 taraf $2=3,15$, taraf $3=3,29$, taraf $4==3,38$, taraf $5=3,43$ dan taraf $6=3,46$ ).

Satriono, $d k k$ (2018) dan Sholihah, $d k k$ (2017) menyebutkan semakin banyak penggunaan bubur nenas dalam adonan maka velva yang dihasilkan akan beraroma nenas. Ini dikarenakan nenas memiliki zat volatil atau zat mudah menguap yang mengeluarkan aroma khas nenas. Menurut Silamba (2011), senyawa metil ester dan etil adalah komponen utama yang memberikan aroma khas nenas.

\section{Rasa}

Berdasarkan hasil penelitian, nilai organoleptik rasa velva nenas sawi berkisar antara 2.09 hingga 3.65 dengan rata rata 2.93 .

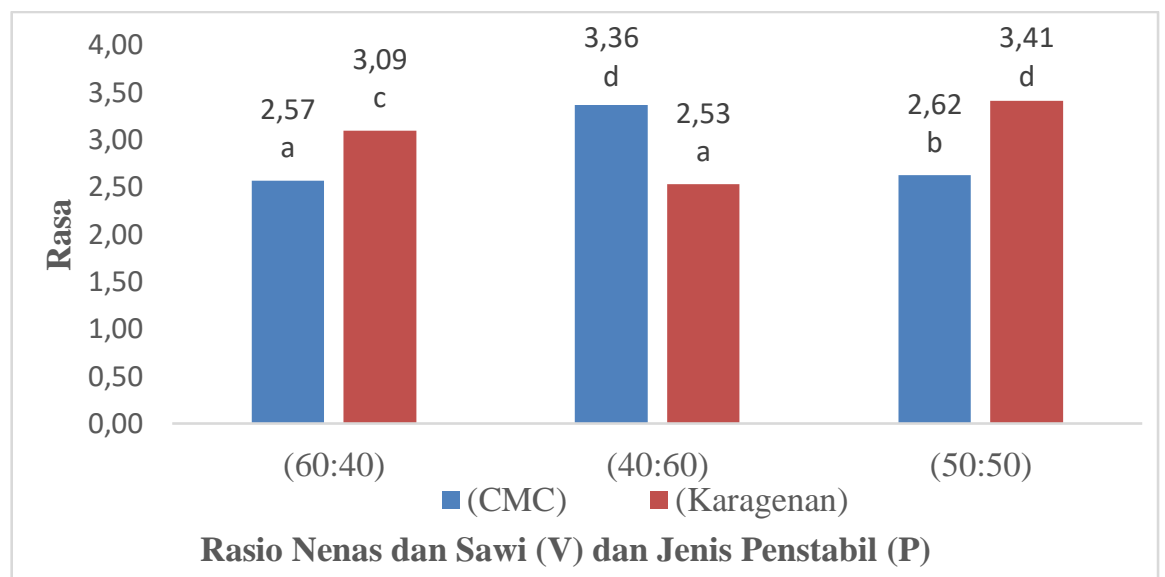

Gambar 7. Pengaruh rasio nenas dan sawi (V) dan jenis penstabil (P) terhadap rasa (Nilai yang diikuti huruf yang berbeda menunjukkan perbedaan yang nyata pada uji DMRT $0,05 \operatorname{taraf} 2=3,15$, taraf $3=3,29$, taraf $4==3,38$, taraf $5=3,43$ dan taraf $6=3,46$ ).

Pada velva dengan penstabil $\mathrm{CMC}$, semakin sedikit nenas yang ditambahkan pada adonan, semakin disukai panelis. Ini diduga rasio nenas dan sawi 60:40 dapat membuat rasa velva menjadi terlalu asam. Menurut Ganz (1977), CMC mempengaruhi batas ambang rasa. Turunnya rasa manis dan naiknya rasa asam dapat terjadi pada produk dengan konsentrasi CMC tertentu. Pada jenis penstabil karagenen, velva dengan rasio 50:50 merupakan nilai rasa tertinggi 
yang disukai panelis. Ini diduga karena rasa velva tidak terlalu manis dan pahit dari sawi juga dapat menetralkan rasa yang terlalu manis.

\section{Tekstur}

Berdasarkan hasil penelitian, nilai organoleptik tekstur velva nenas sawi berkisar antara 2.54 hingga 3.23 dengan rata rata 2.85 . I

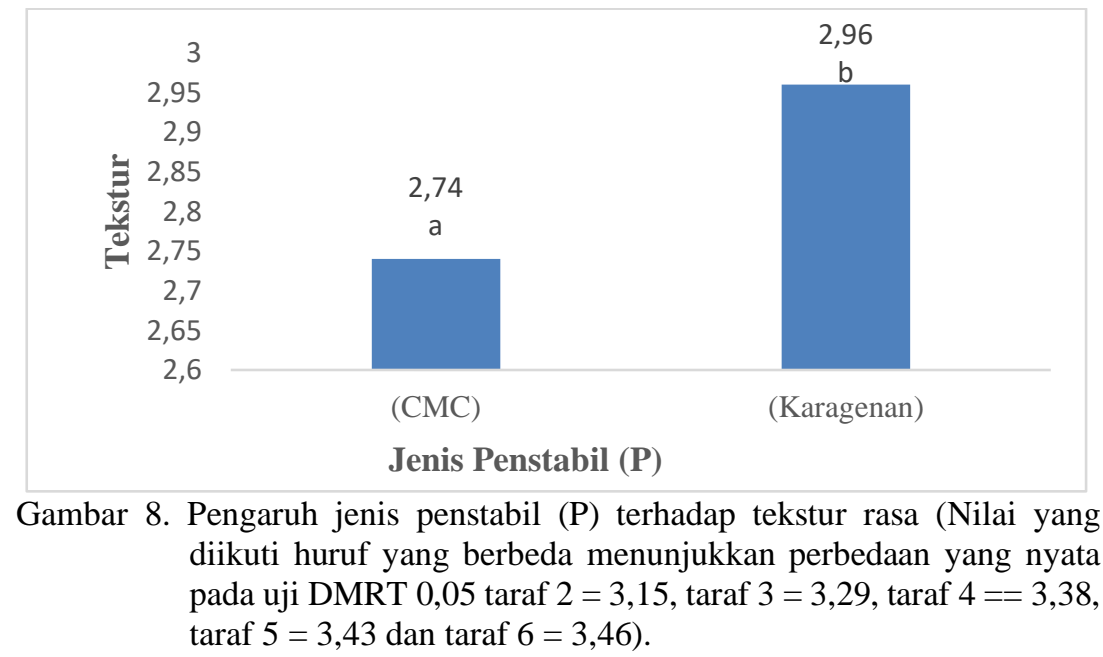

Penambahan karagenan pada adonan velva dapat mengikat air bebas pada produk dan memperkecil ukuran kristal es yang terbentuk. Menurut Masykuri, $d k k$ (2009) es krim coklat dengan penambahan karagenan $0.5 \%$ memberikan pengaruh terhadap tekstur es krim. Menurut Fatoni, $d k k$ (2016) karagenan yang ditambahkan dapat memberikan pengaruh yang nyata terhadap tekstur labu kuning. Menurut Susilowati, $d k k$ (2013) fungsi utama bahan penstabil yaitu mengikat air yang ada pada campuran, sehingga saat penyimpanan tekstur dan body produk dapat dipertahankan.

\section{Overall acceptability}

Menurut Hassanuddin, $d k k$ (2011), penilaian keseluruhan yaitu penilaian kesukaan terhadap produk sacara umum. Berdasarkan hasil penelitian, nilai organoleptik overall acceptability velva nenas sawi berkisar antara 2.48 hingga 3.51 dengan rata rata 3.02.

\section{KESIMPULAN DAN SARAN}

\section{KESIMPULAN}

Adapun kesimpulan dari penelitian ini adalah velva nenas-sawi dengan formula terbaik adalah yaitu dengan rasio nenas dan sawi 40:60 dengan jenis penstabil CMC nilai overrun $34.75 \%$, viskositas $2988.27 \mathrm{cP}$, daya leleh 30.93 menit, serat kasar 14.05, pH 4.71, kadar air $80.69 \%$, kadar abu $0.192 \%$, total padatan terlarut 12.97 , vitamin C $27.37 \mathrm{mg} / 100$ gram. Berdasarkan pengujian hedonik oleh panelis semi terlatih, rasio velva yang paling diminati yaitu rasio nenas dan sawi 50:50 menggunakan penstabil karagenan.

\section{SARAN}

Adapun saran untuk penelitian ini adalah dilakukannya penelitian lanjutan dengan kadar penstabil yang bervariasi untuk mendapatkan rasio yang lebih baik dan melakukan uji organoleptik (uji deskriptif). 


\section{DAFTAR PUSTAKA}

Arbuckle. 1986. Ice Cream. The AVI Publishing, Westport, Connecticut.

Firdaus, S. 2018. Pengaruh Jenis dan Konsentrasi Bahan Penstabil terhadap Mutu Velva Pepaya California (Carica papaya L). Artikel Ilmiah. Fakultas Tenologi Pangan dan Agroindsutri. Universitas Mataram, Mataram.

Harnanik, Sri. 2013. Perbaikan Mutu Pengolahan Nenas dengan Tenologi Olah Minimal dan Peluang Aplikasinya di Indonesia. Jurnal Litbang Pertanian. 2(32) : 67-75.

Jihan, Utin Mutia Alma. 2020. Kajian Pembuatan Es Krim dari Daun Sawi (Brassica juncea L.) dan Tapai Singkong (Manihot utilissima). Skripsi. Jurusan Teknologi Hasil Pertanian Fakultas Pertanian Universitas Syiah Kuala, Banda Aceh.

Kesuma, T.I. 2011. Pengaruh Jenis dan Konsentrasi Pati terhadap Karakteristik Tepung Nenas (Ananas comocus (L) Merr) dan Pengaruh CMC terhadap Karakteristik Velva Berbahan Dasar Tepung Nenas. Skripsi. Fakultas Teknologi Pertanian. ITB, Bogor.

Kumalasari, Ekafitri, Desnlasari. 2015. Pengaru Bahan Penstabil dan Perbahdingan Bubur Buah terhadap Mutu Sari Buah Campuran Pepaya-Nenas. Jurnal Hortikultura. 25(3): 266276.

Kusbiantoro, B., Herawati, H. Ahza, B. 2005. Pengaruh Jenis dan Konsentrasi Bahan Penstabil Terhadap Mutu Produk Velva Labu Jipang. Jurnal Hortikultura. 15(3): 223-230.

Maria, D.N., Zubaidah, E. 2014. Pembuatan Velva Jambu Biji Merah Probiotik (Lactobacillus acidophilus) Kajian Persentase Penambahan Sukrosa dan CMC. Jurnal Pangan dan Agroindustri. 2(4): 18-28.

Nurjannah, E. 2003.Pengaruh Jenis dan Konsentrasi Bahan Penstabil Terhadap Mutu Velva Wortel Daucus curota, L. Jurnal Fakultas Teknologi Pertanian. Institut Pertanian Bogor. Bogor

Pokluda, Robert. 2007. Morphological and Nutritional Parameters of Chinese Mustard (Brassica juncea) in Hydroponic Culture

Priastami. 2011. Karagenan Sebagai Bahan Penstabil pada Proses Pembuatan Melorin. Skripsi, Institut Pertanian Bogor. Bogor.

Satriono. Johan, V.S. dan Hamzah F. 2018. Pemanfaatan Tomat dan Nanas dalam Pembuatan Velva. JOM Universitas Riau. 5(2): 1-15.

Sulastri, T.A. 2008. Pengaruh Konsentrasi Gum Arab Terhadap Mutu Velva Buah Nenas Selama Penyimpanan Dingin. Skripsi. Departemen Teknologi Pertanian. Fakultas Pertanian USU. Medan.

Sholihah, R. Yusmarini. Dan Johan, V.S. 2017. Pemanfaatan Bubur Nenas dalam Pembuaan Velva Ubi Jalar Ungu. JOM FAPERTA. 4(2): 7-12.

Tampubolon, R,H., Yusmarini, Johan. V.S. 2017. Penambahan Buah Nenas dalam Pembuatan Velva Wortel. JOM Faperta. 4(2): 1-15.

Tantono, E., Effendi, R., Hamzah, F.H. 2017. Variasi Rasio Bahan Penstabil CMC (Carboxymethyl Cellulose) dan Gum Arab terhadap Mutu Velva Alpukat (Parsea Americana Mill.). JOM Faperta. 4(2): 1-16.

Ulya, Rahmatul. 2019. Pembuatan Velva Wortel (Daucus Carota L.) - Jeruk (Citrus Sinensis) Dengan Variasi Jenis Penstabil (CMC, Karagenan Dan Gelatin). Skripsi. Jurusan Teknologi Hasil Pertanian Fakultas Pertanian Universitas Syiah Kuala, Banda Aceh. 